\title{
Students' Perceptions on Collaborative Speaking Tasks in ESL Classrooms
}

\author{
Manimegalai Govindasamy' ${ }^{1}$ Parilah Md. Shah ${ }^{2}$ \\ ${ }^{1}$ Sekolah Menengah Kebangsaan Bandar Baru Sentul, Sentul, Malaysia \\ ${ }^{2}$ Universiti Kebangsaan Malaysia, Bangi, Malaysia \\ Email: megmurali@yahoo.com
}

How to cite this paper: Govindasamy, M., \& Shah, P. Md. (2020). Students' Perceptions on Collaborative Speaking Tasks in ESL Classrooms. Creative Education, 11, 2280-2292. https://doi.org/10.4236/ce.2020.1111167

Received: September 22, 2020

Accepted: November 15, 2020

Published: November 18, 2020

Copyright (c) 2020 by author(s) and Scientific Research Publishing Inc. This work is licensed under the Creative Commons Attribution International License (CC BY 4.0).

http://creativecommons.org/licenses/by/4.0/

\begin{abstract}
Speaking is important in learning and teaching of a second language. This paper aims to investigate students' perceptions on collaborative speaking tasks in ESL classrooms by conducting pair work speaking activities. This survey was conducted with 100 Form Three students in a secondary school in Sentul Zone, Federal Territory of Kuala Lumpur. Pair work speaking activities were conducted for five weeks in English language classes in the school, to explore students' views on collaborative speaking tasks. All the students were asked to answer a five-point Likert Scale Questionnaire via Google Form, as the instrument to collect the data for this research. The data was analysed based on two research questions: RQ1: What are the students' perceptions on collaborative speaking tasks? And RQ2: Is there a significant difference between males and females with the respect to their perceptions on the collaborative speaking tasks? The data was analysed by frequency for RQ1 and t-test for RQ2. The findings revealed that the majority of the students prefer pair work speaking tasks as an effective technique to encourage them to speak confidently during their speaking lessons. The positive feedback of their perceptions showed that they can enhance their speaking skill with their peers and the role of their language teachers is only minimal. This study would provide some ideas for teachers to conduct speaking lessons referring to the findings obtained from the students' feedback.
\end{abstract}

\section{Keywords}

Collaborative Learning, Pair Work Speaking Tasks, ESL Classrooms

\section{Introduction}

English, as a second language in Malaysian Education System continues to be a compulsory subject taught in all Malaysian educational institutions. The Com- 
mon European Framework of Reference for Languages (CEFR), a globally recognized framework that was introduced in Malaysia in 2018, was a reformation in the English language education in Malaysia. According to Bueno, Madrid, and McLaren (2006), speaking is one of the most difficult skills language learners must face. Therefore, English classrooms became the basic ideal platform for students to acquire good communication skills to face the era of globalization valiantly. Derakhshan et al. (2015) stated speaking skills have been developing over the past four decades in teaching and learning English as a second language. Teachers need to motivate and inspire students to speak in English during classes. Peer interaction is one of the most important elements in promoting the second language learning (Fitria, 2016). Rao S. P. (2019) states that teachers have to consider the learners' need and interest while selecting topics that can lead the learners to work on the given topics with interest and enthusiasm. Pair work activities are more effective and private compared to group activities in coaching students to speak fluently with their partners (Jones, 2007). According to Moore and Hansen (2011), classroom tasks can engage students in acquiring speaking skills as in a model of the real environment. According to Westbrook (2011, in Achmad \& Yusuf, 2014) stated that students are more comfortable to get engaged in speaking tasks with their pairs and are free to communicate and perceive mistakes between them rather than be coordinated and corrected by their teachers.

Generally, acquiring language skills specifically in speaking skill includes vocabulary, pronunciation, fluency and appropriate grammar. As L2 learners, this skill can be gained through regular spoken interactions with others by emphasizing on the speaking skill elements. According to Keyi (2006), speaking is the most important skill in learning and teaching a language. Boonkit, K. (2010) cited Zaremba (2006) and Zhang (2009) supported Keyi (2006) agreed among the 4 skills in a language, speaking is the most important skill needed in communication. In this study, most of the students are not fluent and unable to narrate and describe the topics assigned to them because of limited vocabulary, shyness, less motivation and have the idea that L2 is not important for their future. In Malaysian education policy, the students are exposed to English language for about 11 years, yet some are unable to speak fluently. This study was investigated when the speaking skills of the researchers' Form 3 students were unsatisfactory. These students will be sitting for Fo, a new way of rerm Three Assessment (PT3) examination. Through observation and experienceaching the students to speak had to be done and collaborative learning was found to be effective. In Malaysia, very few studies had been conducted regarding students' perceptions on collaborative speaking tasks in ESL classrooms. Therefore, the purpose of this study is to investigate students' perceptions on collaborative speaking tasks in ESL classrooms and to distinguish their perception according to gender. In accordance to this, the research questions that guided this study are:

1) What are the students' perceptions on collaborative speaking tasks?

2) Is there a significant difference between males and females with the respect to their perceptions on the collaborative speaking tasks? 
This study which focuses on students' perception on collaborative speaking tasks in ESL classrooms, would provide useful feedback from the distributed questionnaires for the teachers to plan, organize and strategies ways to help students in enhancing their speaking skill through pair work activities. Awareness of their students' needs will be focused and practiced during teaching and learning in future. The study would also assist other researchers or teachers teaching L2 in Malaysian schools to take the necessary steps in organizing pair work activities in classrooms during speaking lessons. The findings will also further facilitate the curriculum developers in the Malaysian Ministry of Education to look into the importance of collaborative speaking tasks in teaching and learning L2. In short, this study will benefit the language teachers and the ESL learners to teach and learn speaking in a different dimension.

\section{Literature Review}

\subsection{Collaborative Based Tasks in Speaking}

In this new era of education, collaborative based tasks are being implemented as an important element in the educational approach in enhancing students' language skills. This approach engages them to work with each other on the assigned tasks where they must collaborate as a group to solve the given problems and promote deeper learning. Moreover, the effectiveness, learning achievement and learners' satisfaction were supported in many studies conducted related to collaborative learning. Laal and Ghodsi (2012) state collaborative learning enables the learners to solve problems and complete given tasks by learning and working in groups. Herrmann (2013) says all the group members will be interdependent on one another. According to Linton et al. (2014), students in groups achieved better understanding compared to students working individually because students of collaborative learning were provided with social skills needed for their future. Vygotsky (1962) states that people learn through interactions and communications with others and surveyed on how social environments influence the process of learning. According to Smith and MacGregor (1992), Vygotsky's social constructivism is an umbrella term for many approaches in the field of education involving intellectual effort by students, teachers or both. Therefore, implementing collaborative learning is important in enhancing students' language learning skills: listening, speaking, reading and writing. According to Laal \& Ghodsi (2012) that has cited Yager and his colleagues (1985) mentioned collaborative learning helped students to enhance their oral communication skills. It should be carefully planned and ensure each student contributes their knowledge, skills and personal experiences during the activities in classrooms. According to Roseth et al. (2008) in a meta-analysis enclosing of 80 years of research stated that students participate actively and developed positive attitudes towards other peers when they are working collaboratively.

\subsection{Enhancing Pair Work in ESL Classrooms}

Encouraging students to speak in English through the concept of pair work tasks 
with their partners is more active compares to individual or group activities because sometimes better students would dominate the discussions and the rest would be passive listeners (Jones, 2007). Nowadays, pair work interactions are used in English language classrooms to motivate students to communicate with their peer as their partners. According to Scrivener (2005), pair work is a classroom interaction involving a student to work with another student by discussing and giving feedback during communicative activities. Students in pairs are capable of doing many tasks (Harmer, 2007). McDonough (2004) explained in learning a foreign language the effectiveness of pair work is better than group tasks. Pair work activities actually assist students to share and exchange ideas during discussions. Touhid T. (2018) had cited Bercikova (2007: 12) explaining that pair work is a form of interaction in classrooms where students communicate during discussions to share their opinions. Furthermore, pair work activities need to be organised in classrooms to see the effectiveness among students in speaking. Main focus of pair work in speaking is not only to mould students to be proficient in the language but also to communicate continuously and think critically. Learning to think critically in pair work tasks can be an important knowledge in students' lifelong journey. Baines, Blatchford and Kutnick (2016) explains the assigned pair work tasks would encourage "critical thinking through analyzing, synthesizing and evaluating ideas". Touhid T. (2018) cited Abdull (2011) about his study that uses pair work technique in improving communicative skills of young learners in UEA and found out the strategy was effective in ESL classroom because it gives the learners to learn the language in a meaningful way. Based on the references above, Malaysia's decision to adopt CEFR framework (2013) in teaching and learning English language in the primary and secondary education is a good choice because the activities designed for the language skills in the textbooks encourage students to communicate with their pairs or group members to complete the given tasks. The interaction between the students during the speaking activities should be enhancing students speaking skills. Enhancing pair work in ESL classroom is not an easy task to be conducted. Thus, teachers and students should work together in making it a success. Teachers or educator's role is to have an overview picture of their lesson that would benefit the students and help them to achieve the objective of their lesson.

\section{Methodology}

\subsection{Population and Sample}

Purposive sampling, which based on Creswell et al. (2011), is involving identified individuals or groups of individuals that are knowledgeable or experienced with the phenomenon of interest, was chosen as the sampling method for this study.

This study was conducted in a government secondary school in the federal Territory of Kuala Lumpur in an urban area. The classes chosen for this research are four Form 3 classes and the students in these classes are mixed ability stu- 
dents. There was a total of 100 students of Form 3 consisting of 44 male students and 56 female students. Researcher prepared these students for their PT3 Speaking Assessment under CEFR. The students were evaluated in pairs to answer general questions, talk about a picture story and discuss about a topic in front of the assessor. Students should have the language proficiency, vocabularies and fluency to deliver points and involve in arguments to make decision with their pairs. The teacher assigned to conduct the collaborative (pair work) speaking task is teaching in the same school and handles all the four classes. She is a BA (English Language Studies) Hons from a local university and has a Diploma in Education in English. She has been teaching English language for Form 3 students for sixteen years. This teacher was selected because she is one of the trained teachers for $21^{\text {st }}$ century learning. This study was divided into two parts. The first part of data collection was conducting the pair work tasks with the students during their speaking lessons in the English language room. The second part would be answering the questionnaire regarding their perceptions on collaborative speaking tasks in ESL classrooms at the school's computer lab and students will be shared the link.

\subsection{Instrument: Questionnaires}

For this study, the researcher used the online questionnaire as the instrument for this qualitative research. The questionnaire was created using google doc and the link was shared with the respondents to answer via online. Murgan, M.G. (2015) explained that questionnaires are always designed to refer to questions that are related to studies to investigate general opinions of a situation. Furthermore, Likert scale items can show high validity and reliability to measure attitudes if the researcher could create items based on strong theoretical assumptions and the rating scales items (Moussu, 2006). The researcher adapted the questionnaire on Effectiveness of Pair Work in ESL Classrooms developed by Touhid (2018), for this study. The five-point Likert-scale was used to structure 23 closed-ended items in the questionnaire. As for the validity, the questionnaire has been reviewed and analysed by Dr. Parilah Mohd Shah, the supervisor for the researcher. The questionnaire for this study is divided into Section A that describes the respondents background and Section B, which analyses the students' perceptions on collaborative speaking tasks in ESL classrooms.

\subsection{Data Collection Procedure}

The chosen teacher conducted collaborative speaking tasks with 100 students for 5 weeks. Each week 2 lessons. Only after exposing students to the speaking task in pair work during the lessons, the questionnaire was distributed to the students of this survey to know their perceptions and analysed the effectiveness of pair work. After the activities were completed by the teacher in charge, only then the researcher distributed the questionnaire to the students to find out their perceptions of the pair work speaking tasks. The questionnaire was answered by the students in the school's computer lab. 


\section{Findings}

\subsection{Findings on Research Question 1}

Table 1 shows the students' perceptions on collaborative learning specifically on pair work tasks in ESL classrooms.

Item 1 to 3 in Table 1 represents the subtopic on students' opinions regarding pairing strategies during pair work speaking tasks. Analysis of Item 1 shows that students $100 \%$ agreed to work in pairs than individually. This shows their positivity in participating in pair work activities for their speaking lessons. Respondents believe in pairs they could exchange ideas in solving a task together confidently. In Item 2, all the respondents agree (33.3\%) and strongly agree (66.7\%) in choosing their own pairs during collaborative speaking tasks as they will not feel shy to speak with a person they know. For Item 3, 16.7\% of the students disagree to work with a pair that is higher than them, $26.7 \%$ agree to the statement and majority strongly believe in working with the higher-level partners. The student's preference for a better partner can be seen in this item. Therefore, this subtopic can be concluded that most of the students agree to work in pairs, choose their own pairs and prefer working with pair that is higher level than them.

Table 1. Respondents' perceptions on collaborative speaking tasks.

\begin{tabular}{|c|c|c|c|c|c|}
\hline ITEM & $\begin{array}{c}\text { Strongly } \\
\text { Disagree (\%) }\end{array}$ & $\begin{array}{c}\text { Disagree } \\
(\%)\end{array}$ & $\begin{array}{c}\text { Not Sure } \\
(\%)\end{array}$ & $\begin{array}{l}\text { Agree } \\
(\%)\end{array}$ & $\begin{array}{c}\text { Strongly Agree } \\
(\%)\end{array}$ \\
\hline 1 & & & & & 100.0 \\
\hline 2 & & & & 33.3 & 66.7 \\
\hline 3 & & 16.7 & & 26.7 & 56.7 \\
\hline 4 & & & 30.0 & 43.3 & 26.7 \\
\hline 5 & & & & 40.0 & 60.0 \\
\hline 6 & & & 33.3 & 26.7 & 40.0 \\
\hline 7 & & & & 30.0 & 70.0 \\
\hline 8 & & 16.7 & & 60.0 & 23.3 \\
\hline 9 & & 16.7 & & 43.4 & 40.0 \\
\hline 10 & & & 10.0 & 53.3 & 36.7 \\
\hline 11 & & & & 33.3 & 66.7 \\
\hline 12 & & & 20.0 & 66.7 & 13.3 \\
\hline 13 & 10.0 & & 16.7 & & 73.3 \\
\hline 14 & & & & 43.3 & 56.7 \\
\hline 15 & & & & 83.3 & 16.7 \\
\hline 16 & & & 6.7 & 43.3 & 50.0 \\
\hline 17 & & & & & 100.0 \\
\hline 18 & & & & 86.7 & 13.3 \\
\hline 19 & & & 26.7 & 56.7 & 16.7 \\
\hline 20 & & & & & 100.0 \\
\hline 21 & & 56.7 & & 43.3 & \\
\hline 22 & 100.0 & & & & \\
\hline 23 & & 40.0 & 60.0 & & \\
\hline
\end{tabular}


Students perceptions on the effectiveness of collaborative speaking tasks are the second subtopic for the RQ1. The researcher had chosen to focus on pair work speaking tasks in the collaborative learning. Items 4 to 17 represent the effectiveness of pair work speaking tasks among the respondents of this study. Item 4 and 5 are referring to the need of teachers during speaking lessons. A total of $70 \%$ of students agree and strongly agree that the assigned pair work activities give them the opportunity to work without teachers help and $30 \%$ of the respondents are unsure of their decision whether they can learn better with their peers or they need their teacher's guidance. Item 5 shows all the respondents $60 \%$ strongly agree and $40 \%$ agree by stating discussing speaking tasks with their partner is more effective than discussing with teachers. A total of $66.7 \%$ respondents feel motivated to speak without tension with their peers and 33.3\% are unsure. Pair work speaking tasks helps all the respondents to be confident to speak fluently and $83.3 \%$ are active in pair work speaking tasks during lessons. $16.7 \%$ admitted they were neither active nor feels responsible during speaking lessons. The data identified $90.0 \%$ of responded were able to reduce their anxiety during pair discussions.

Even though there were some unsure perceptions and disagreement of some items, all the respondents agreed pair work speaking tasks enhanced their speaking skill. The respondents' view on uttering error free sentences with proper grammar and vocabulary through the pairing speaking task reveals positivity as $66.7 \%$ agrees and $13.3 \%$ disagree. Although the frequency for Item 13 shows $73.3 \%$ of the students feel the given tasks helped them in receiving helpful and useful feedbacks, $10.0 \%$ of respondents do not agree and leaving $16.7 \%$ were under conflict of the benefit. Moreover, respondents' views concerning their improvement in pair work speaking classes by fostering knowledge, information and experience were showing positivity from all of them. Furthermore, most of the respondents agreed the task-based pair activities stimulated their critical thinking, yet about $6.7 \%$ were not sure. Item 17 reveals, classroom interaction motivates students to respond during class discussions $100 \%$.

Students' opinions related to negative aspects of pair work speaking tasks was analyzed from Item 18 to 23 . Misunderstanding occurs among the respondents most of the time because the findings revealed $86.7 \%$ agree and $13.3 \%$ strongly agree for the statement. They also find it difficult when their pair leads the discussion as $56.7 \%$ agree and $16.7 \%$ strongly agree. $26.7 \%$ respondents were not sure. All the respondents strongly agree to the statement pair work will not be effective for students who are introvert during the lesson. Besides that, $43.3 \%$ of the respondents agree that students who are linguistically weak create anxiety. However, at the same time $56.7 \%$ disagree to the statement above. Although, every respondent agreed that pair work was not a waste of time and $40.0 \%$ agreed their peers should guide them rather than their teachers but $60.0 \%$ of the respondents were not sure whose role is more dominant in guiding them to speak. 
As to conclude RQ1's findings, above $50 \%$ of rate shows advantages comparing to minimal disadvantages regarding students' perceptions on collaborative speaking tasks in ESL classrooms.

\subsection{Findings on Research Question 2}

An independent-sample t-test was analyzed to compare students' perception scores for male and female students for this study. The result is displayed in Table 2.

Referring to the above result, an independent sample t-test was conducted to compare the perceptions on collaborative speaking tasks among male and female students. There were 30 respondents in this study, 13 male students and $17 \mathrm{fe}-$ male students. The finding indicates there was significance difference in the score of pairing strategies for male $(\mathrm{M}=13.31, \mathrm{SD}=1.109)$ and female $(\mathrm{M}=$ $14.35, \mathrm{SD}=0.862)$ conditions; $t(28)=-2.908, p=0.007$. Furthermore, the average score of male students is significantly lower than the average score of female students. Therefore, this result suggested that, female students were good at pairing strategies compared to male students. However, study also revealed that there was no significant difference in score of effectiveness with $(t(28)=0.979, p$ $=0.336)$ and negative aspect $(t(28)=0.131, p=0.897)$ among the gender. Therefore, the score between male and female students towards effectiveness of task-based pair speaking tasks and negative aspect is consistent.

In this study, the researcher had analyzed the respondents' perceptions according to gender to see each gender has the equal ability to grasp the speaking skill through pair work speaking task or not. The results of the analysis revealed that there isn't any significant difference among male and female respondents in coping with the collaborative speaking tasks in ESL classrooms. Therefore, the results of the data give confidence for language teachers to apply this strategy in enhancing students speaking skill during speaking classes.

\section{Discussion, Conclusion and Recommendation}

\subsection{Discussion}

The results of this study summarize that the students' perceptions have positive attitude towards practicing collaborative speaking tasks in their English language classes. Pair work task helps to create a collaborative environment for the students

Table 2. Gender perceptions on collaborative speaking tasks.

\begin{tabular}{|c|c|c|c|c|c|c|}
\hline \multirow{3}{*}{ Variables } & \multicolumn{6}{|c|}{ Gender } \\
\hline & \multicolumn{2}{|c|}{ Mean (SD) } & \multirow{2}{*}{$t$-stats } & \multirow{2}{*}{$\begin{array}{c}\text { Sig. } \\
\text { (2-tailed) }\end{array}$} & \multicolumn{2}{|c|}{$95 \% \mathrm{CI}$ of difference } \\
\hline & Male & Female & & & Lower & Upper \\
\hline Pairing strategies & $13.31(1.109)$ & $14.35(0.862)$ & -2.908 & 0.007 & -1.782 & -0.309 \\
\hline Effectiveness & $60.62(2.987)$ & $59.59(2.740)$ & 0.979 & 0.336 & -1.123 & 3.177 \\
\hline Negative aspect & $19.54(1.450)$ & $19.47(1.375)$ & 0.131 & 0.897 & -0.994 & 1.130 \\
\hline
\end{tabular}


to enhance their speaking skill. This result was supported by Lightbrown and Spada (2006) stating pair work strategy helps to develop student's language proficiency in performing an activity successfully. All the students (100\%) preferred to work in pairs, not individually and mentioned it is not a waste of time involving themselves in pair work activities. The statement aligns with the studies by Harmer (2007) mentioned students in pairs are capable of doing many tasks and Laal and Ghodsi (2012) stated collaborative learning enables the learners to solve problems and complete given tasks by learning and working in groups.

Moreover, the findings revealed collaborative speaking tasks reduced students' anxiety when they worked in pairs and it helped them in enhancing their speaking skills. Jones (2007) supported the findings by mentioning students who are calm and stress-free can learn a language better. Raja and Saeed (2012) in her study reported students working with their pairs in completing a task feel tensionless because they enjoy the strategy. This occurs maybe the peers could help them to solve the problems which lead to understanding the tasks better. Harmer (2007) mentioned in pair work the learners could complete a task successfully without teachers' guide.

Next, practicing collaborative speaking tasks using pair work technique brings advantages to most of the pairs. First, $26.7 \%$ agree and $40.0 \%$ strongly agree this learning motivates them to speak. Jones (2007) reports during pair work increases the learners' motivation as it reduces the monotony of learnings. Baleghizadeh and Farhesh (2014) in their study stated classroom pair work participation encourages and motivates students. Second, students 100\% feel that they can solve and respond faster when opinions are requested during speaking lessons because they receive helpful feedbacks from their pairs as $73.3 \%$ strongly agree to the statement in Item 13. Baleghizadeh and Farhesh (2014) stated students were given the opportunity to share their knowledge and resources during the activities. Third, a total of $93.3 \%$ students agree and strongly agree the collaborative speaking tasks stimulated their critical thinking (White and Pea, 2011; Dillenbourg (1999); Ingleton et al., 2000). Mosley, et al. (2016) stated there are many findings supported that collaborative learning was enhancing critical thinking among students. Furthermore, in pairing up strategies' students prefer to work with the pair of their choice (agree: $33.3 \%$, strongly agree: $66.7 \%$ ) and a total of $83.4 \%$ prefer to pair up with a higher-level pair. Generally, a higher-level pair can share, guide and are more knowledgeable. Zohairy (2014) supports the statement above as he mentioned in his studies stated learners prefer to involve in higher level pairs because they can provide better knowledgeable resources. Baines, Blatchford and Kutnick (2016) mentioned students like to pair up with a better pair as some can put in less afford that leads to unequal performances. From the findings $16.7 \%$ disagree to pair up with a better pair. Reasons could be to avoid misunderstandings and creating a symmetrical relationship with their pairs. Harmer (2001) stated pair work can cause problems when another pair is linguistically weak. Zohairy (2014) supports to the findings mentioning misunderstanding between pairs occurs when the pair fails to participate actively. Do- 
mination occurs in pair work causing misunderstanding (Zohairy, 2014). Anxiety among some students who are linguistically weak (43.3\%) causes problem in collaborative speaking tasks. This is similar to a study carried out by Tomlinson (2016) addressed pair work creates anxiety among linguistically weak students. Problems arise in pair work when one of the pair becomes more relaxed by remaining silence or reluctant to participate in interactive tasks (Chowdhury, 2005).

The research findings on Item 23 regarding teachers' need to guide students to speak fluently not their pairs show students can't be totally independent without teachers guide. $40 \%$ of the respondents disagree and $60 \%$ are not sure. Chu and Nakamura (2010) stated students in Japan and Taiwan still preferred and mostly wanted their teachers guide. Harmer (2001) stated weaker students needed extra care and couching from their teachers. The students who gained benefits confidently stated they can manage yet the $60 \%$ that are not sure might be the group of respondents who faces problems with their peers or weak students that had problem in pairing up. Storch and Aldosari (2013) support by stating if low proficiency student if paired with high proficiency students would cause asymmetrical relationship. Therefore, here teachers play the role considering students' abilities and suitable learning styles before involving them in collaborative learning tasks. Overall, the findings in this study had helped students to achieve both accuracy and fluency using proper grammar and vocabulary through collaborative speaking tasks. This finding supported with Richards and Bohlke, (2011) mentioned continuous interaction in pair work develops ones both accuracy and fluency. Thus, Coskun (2011) adds fluency develops without teacher's interference during pair work tasks. The findings too showed students feel it's more effective when they discuss with their peers in Item 5 . The researcher can conclude stating that pair work as one of the elements in collaborative learning can improve students' speaking skill through collaborative speaking tasks. Students proficiency in second language can improve students' performances in their CEFR Speaking Assessment in their PT3 examination among Form Three students.

\subsection{Conclusion}

The findings of this research suggested that students believe in pair work speaking tasks can strongly influence students' speaking proficiency based on the findings on students' perceptions on this study. Enhancing speaking through collaborative speaking tasks, students feel inspired, motivated, confident, relaxed, will be more critical and will show improvement in grammar and pronunciation that leads to fluency. Teachers' awareness and implementation of activities based on the students' ability and capability can lead to overcoming the minor problems that had been encountered. A successful student-centred classroom environment can be created with teachers being the moderator to enhance speaking skills by implementing pair work speaking tasks in ESL classrooms. However, there are some limitations even though students are positive towards 
this strategy.

As to conclude, in the era of $21^{\text {st }}$ century, teachers should adapt to the latest changes in the world of education. Many strategies have been introduced and practised to encourage students to acquire the skills in learning a target language. As teachers, they should try to motivate and find strategies that can attract them to show interest. As from this study, pair work speaking tasks have proved that the majority of the students prefer to enhance their speaking skills through activities by collaborating with their peers rather than teachers playing their role. Teachers must adapt to the new way of educating students or else they will be left behind, and it would reflect on their students' achievement. Therefore, students should be given the opportunities to communicate in the real-life environment through collaborative speaking tasks.

\subsection{Recommendation}

For future studies, it is recommended for the other researchers to conduct pre-test and post-test on this study before distributing the questionnaire to see comparison from students' perception and teachers' observation for a better view. Interviews or open-ended questions too should be included in the questionnaire to know students' viewpoints for certain disagreements. Besides that, researchers can combine other strategies or methods together with collaborative learning strategy in enhancing students speaking skill. Therefore, each student can benefit from the suggestions and gives opportunity to teachers to play their role effectively.

\section{Acknowledgements}

First and foremost, my utmost gratitude to the God Almighty for His blessing and kindness in rewarding me with good health, patience, strength and endurance to complete my study. My sincere appreciation goes out to my supervisor, Dr. Parilah Mohd Shah for her constant guidance, assistance and support throughout the study. Her constructive advices and concern have helped me to go through most of my difficult time in writing this research paper. Most importantly, my deepest appreciation goes to my parents, En. Govindasamy A/L Munusamy and Pn. Saraswathy A/P Ponnusamy, my parents in law, En Muthusamy Karuppanan and Pn Pavanambal Periathamby, who never stops believing in me, guiding and supporting me throughout my studies. To my children, Mohiith Murali and Mohinh Murali, one day you will see me in yourselves. To my family, brothers, sisters, brother in laws and sister in laws, thank you for the encouragement and support when I need them around. I am very much thankful to friends and colleagues for all their encouragement and support specially to $\mathrm{Mu}-$ thu, Kala, Manju and Sugi. Last but not least, many thanks to the one and all who, directly and indirectly, have helped me in this venture.

\section{Conflicts of Interest}

The authors declare no conflicts of interest regarding the publication of this paper. 


\section{References}

Achmad, D., \& Yusuf, Y. Q. (2014). Observing Pair-Work Task in an English-Speaking Class. International Journal of Instruction, 7, 151-164.

Baines, E., Blatchford, P., \& Kutnick, P. (2016). Promoting Effective Group Work in the Primary Classroom: A Handbook for Teachers and Practitioners. Abingdon-on-Thames: Routledge. https://doi.org/10.4324/9781315730363

Baleghizadeh, S., \& Farhesh, S. (2014). The Impact of Pair Work on EFL Learners' Motivation. MEXTESOL Journal, 38, 1-11.

Boonkit, K. (2010). Enhancing the Development of Speaking Skills for Non-Native Speakers of English. Procedia-Social and Behavioral Sciences, 2, 1305-1309.

https://doi.org/10.1016/j.sbspro.2010.03.191

Bueno, A., Madrid, D., \& McLaren, N. (2006). TEFL in Secondary Education (pp. 4-7). Granada: Editorial Universidad de Granada.

Chowdhury, S. (2005). Interaction in Second Language Classrooms.

Chu, M. P., \& Nakamura, T. (2010). A Study of Chinese and Japanese College Students' L2 Learning Styles. Asian Culture and History, 2, 30. https://doi.org/10.5539/ach.v2n2p30

Coskun, A. (2011). Investigation of the Application of Communicative Language Teaching in the English Language Classroom-A Case Study on Teachers' Attitudes in Turkey. Journal of Linguistics and Language Teaching, 2, 85-109.

Creswell, J. W., Klassen, A. C., Plano Clark, V. L., \& Smith, K. C. (2011). Best Practices for Mixed Methods Research in the Health Sciences (pp. 541-545). Bethesda, MD: National Institutes of Health. https://doi.org/10.1037/e566732013-001

Derakhshan, A., Tahery, F., \& Mirarab, N. (2015). Helping Adult and Young Learners to Communicate in Speaking Classes with Confidence. Mediterranean Journal of Social Sciences, 6, 520. https://doi.org/10.5901/mjss.2015.v6n2p520

Dillenbourg, P. (1999). What Do You Mean by Collaborative Learning?

Fitria, R. (2016). Analysing the Characteristics of a Pair Talk on an Editing Task on Two Intermediate Indonesian Learners of English. Englisia: Journal of Language, Education, and Humanities, 4, 42-54. https://doi.org/10.22373/ej.v4i1.1293

Harmer, J. (2007). The Practice of English Language Teaching. Harlow: Pearson Education.

Herrmann, K. J. (2013). The Impact of Cooperative Learning on Student Engagement: Results from an Intervention. Active Learning in Higher Education, 14, 175-187. https://doi.org/10.1177/1469787413498035

Ingleton, C., Kiley, M. M., Cannon, R. A., \& Rogers, T. (2000). Leap into ... Student-Centred Learning.

Jones, L. (2007). The Student-Centered Classroom.

Keyi, H. (2006). Teaching Speaking: Activities to Promote Speaking in a Second Language. The Internet TESL Journal, 12.

Laal, M., \& Ghodsi, S. M. (2012). Benefits of Collaborative Learning. Procedia-Social and Behavioral Sciences, 31, 486-490. https://doi.org/10.1016/j.sbspro.2011.12.091

Lightbrown, P. M., \& Spada, N. (2006). How Languages Are Learnt (3rd ed.). New York: Oxford University Press.

Linton, D. L., Farmer, J. K., \& Peterson, E. (2014). Is Peer Interaction Necessary for Optimal Active Learning? CBE-Life Sciences Education, 13, 243-252. 
https://doi.org/10.1187/cbe.13-10-0201

McDonough, K. (2004). Learner-Learner Interaction during Pair and Small Group Activities in a Thai EFL Context. System, 32, 207-224. https://doi.org/10.1016/j.system.2004.01.003

Moore, K. D., \& Hansen, J. (2011). Effective Strategies for Teaching in K-8 Classrooms. Thousand Oaks, CA: Sage. https://doi.org/10.4135/9781452230511

Mosley, P., Ardito, G., \& Scollins, L. (2016). Robotic Cooperative Learning Promotes Student STEM Interest. American Journal of Engineering Education, 7, 117-128. https://doi.org/10.19030/ajee.v7i2.9895

Moussu, L. M. (2006). Native and Non-Native English-Speaking English as a Second Language Teachers: Student Attitudes, Teacher Self-Perceptions, and Intensive English Administrator Beliefs and Practices.

Murgan, M. G. (2015). A Critical Analysis of the Techniques for Data Gathering in Legal Research. Journal of Social Sciences and Humanities, 1, 266-274.

Raja, N., \& Saeed, A. (2012). The Effectiveness of Group Work and Pair Work for Students of English at Undergraduate Level in Public and Private Sector Colleges. Interdisciplinary Journal of Contemporary Research in Business, 4, 155-163.

Rao, P. S. (2019). The Importance of Speaking Skills in English Classrooms. Alford Council of International English \& Literature Journal, 2, 6-18.

Richards, J. C., \& Bohlke, D. (2011). Creating Effective Language Lessons. Cambridge: Cambridge University Press.

Roseth, C. J., Garfield, J. B., \& Ben-Zvi, D. (2008). Collaboration in Learning and Teaching Statistics. Journal of Statistics Education, 16.

https://doi.org/10.1080/10691898.2008.11889557

Scrivener, J. (2005). Learning Teaching, a Guidebook for English Teachers.

Smith, B. L., \& MacGregor, J. T. (1992). What Is Collaborative Learning.

Storch, N., \& Aldosari, A. (2013). Pairing Learners in Pair Work Activity. Language Teaching Research, 17, 31-48. https://doi.org/10.1177/1362168812457530

Tomlinson, B. (2016). SLA Research and Materials Development for Language Learning. Abingdon-on-Thames: Routledge. https://doi.org/10.4324/9781315749082

Touhid, T. (2018). Effectiveness of Pair Work Activities in ESL Classrooms at the Tertiary Levels of Bangladesh. Doctoral Dissertation, Bangladesh: Brac University.

Vygotsky, L. S. (1962). Thought and Language. Cambridge, MA: MIT Press. https://doi.org/10.1037/11193-000

White, T., \& Pea, R. (2011). Distributed by Design: On the Promises and Pitfalls of Collaborative Learning with Multiple Representations. Journal of the Learning Sciences, 20, 489-547. https://doi.org/10.1080/10508406.2010.542700

Yager, S., Johnson, D. W., \& Johnson, R. T. (1985). Oral Discussion, Group-to-Individual Transfer, and Achievement in Cooperative Learning Groups. Journal of Educational Psychology, 77, 60. https://doi.org/10.1037/0022-0663.77.1.60

Zhang, Y. (2009). Reading to Speak: Integrating Oral Communication Skills. English Teaching Forum, 47, 32-34.

Zohairy, S. (2014). Effective Pairwork Strategies to Enhance Saudi Pre-Intermediate College Students, Language Production in Speaking Activities. European Scientific Journal, 10,50 . 